\title{
Successful management of pregnancy and delivery in a patient with ventriculoperitoneal shunt malfunction: a case report and review of recent literature
}

\begin{abstract}
Ventriculoperitoneal shunt (VP) shunts are a definitive treatment for hydrocephalus. Women successfully treated for hydrocephalus and reproductive aged women with a shunt are becoming pregnant. The most common complication of VP shunt is shunt malfunction during pregnancy. We report a case of pregnancy in a woman with ventriculoperitoneal shunt malfunction and reviewed the currently available literature regarding pregnancy and delivery in patients with VP shunt. In our case, a 29 year-old woman who was at 37 weeks of gestation, was admitted to the neurosurgery clinic of our hospital with a complaint of headache, dizziness, urinary and fecal incontinence. The patient was diagnosed with a VP shunt dysfunction. She had a ventriculoperitoneal shunt placed 3 years ago for idiopathic hydrocephalus treatment. Due to her rapid deteriorating neurological status, cesarean delivery was performed without intrapartum and postpartum complications. In these women the management must be individualized, multi disciplined and close collaboration with the neurosurgeon, obstetrician and anesthesiologist offer the best chance of normal pregnancy and delivery. In this review, we would like to discuss VP shunt cases during pregnancy in the light of recent literature.
\end{abstract}

Keywords: ventriculoperitoneal shunt, shunt malfunction, maternal hydrocephalus, pregnancy, management
Volume 9 Issue 5 - 2018

\section{Fatma Yazici Yilmaz,' Begum Aydogan}

Mathyk, ${ }^{2}$ Nefise Nazli Yenigul, ${ }^{3}$ Isil Ayhan ${ }^{4}$

'Obstetrics \& Gynecology, Sisli Etfal Training \& Research Hospital,Turkey

${ }^{2}$ Department of Obstetrics and Gynecology, Division of Reproductive Endocrinology and Infertility, University of North Carolina, USA

${ }^{3}$ Department of Obstetrics and Gynecology, Sanliurfa Training and Research Hospital,Turkey

${ }^{4}$ Department of Obstetrics and Gynecology, Zeynep Kamil Women's and Children's Disease Training and Research Hospital, Turkey

Correspondence: Fatma Yazici Yilmaz, MD, Obstetrics \& Gynecology, Halaskargazi Street, Sisli Etfal Training \& Research Hospital, Istanbul, Turkey, Tel +905442292242, Fax +902122240772, Email fatmayizc@gmail.com

Received: February 24, 2018 | Published: October 29, 2018
Abbreviations: VP, ventriculoperitoneal shunt; ICP, intracranial pressure

\section{Introduction}

A Ventriculoperitoneal (VP) shunt is the most common and effective procedure for the treatment of hydrocephalus. ${ }^{1}$ Women successfully treated for hydrocephalus and reproductive aged women with a shunt are becoming pregnant. In the literature, there have been still published various complications during pregnancy and delivery. Some studies pointed to a high incidence of complications for some pregnant patients with VP. ${ }^{2}$ On the contrary, some studies reported the presence of a VP shunt does not affect pregnancy outcomes. ${ }^{1,3}$ Possible complications are shunt malfunction, shunt failure, and shunt infection. ${ }^{4}$ The most common complication of VP shunt is shunt malfunction during pregnancy. The VP shunt catheter is frequently obstructed during the third trimester as a result of increased intraabdominal pressure. ${ }^{5}$ The most common symptoms of shunt malfunction include headache, nausea and vomiting. ${ }^{4,6,7} \mathrm{~A}$ standard managament for shunt malfunction during pregnancy has not been established yet. ${ }^{6}$ The management of pregnancy in women with shunt malfunction is determined by the underlying pathology, the neurological status of the patient and the gestational age at the time of diagnosis. ${ }^{8}$ Most authors considered vaginal delivery as the first option, but this choice depends on both obstetrical indications and neurosurgical factors. ${ }^{3,7,9}$ The choice of an anaesthetic procedure for cesarean delivery in a patient with a malfunctioning VP shunt depends on a variety of factors. Moreover, there is constant debate on the preference of anaesthetic techniques in pregnant women with a VP shunt.

In our case report a patient with a VP shunt malfunction presented with progressive neurological deterioration in the third trimester of her pregnancy. We performed a cesarean delivery under spinal anesthesia without intrapartum and postpartum complications. In this review, we aimed to present our successfully managed case and would like to discuss VP shunt cases during pregnancy in the light of recent literature.

\section{Case report}

A 29 year-old woman gravida 3 para 0 , abortion 2, who was at 37 weeks of gestation, was admitted to the neurosurgery clinic of our hospital with a complaint of headache, dizziness, urinary and fecal incontinence. Her history showed complaints of gait imbalance and a headache for the past 3 months. Recently in the last month she developed urinary and fecal incontinence. Her neurological examination revealed a loss of balance and a loss of anal and urinary sphincter tones. A cranial CT scan showed dilatation of both the lateral ventricles and the third ventricle (Figure 1). The patient was diagnosed with a VP shunt dysfunction. She had a ventriculoperitoneal shunt placed 3 years ago for idiopathic hydrocephalus treatment. She had an approval from her neurosurgeon prior to her pregnancy. After her complaints, she was referred to our department. On the obstetrical ultrasonography, fetal biometric measurements were consistent with the 37 weeks of gestation. The amniotic fluid index was normal and no placental pathology was observed. Due to her rapid deteriorating neurological status, cesarean section under spinal anesthesia was planned with the recommendation of neurosurgeons. During the operation the abdominal section of the shunt was observed observed in appropriate localization. A healthy male infant weighing $3240 \mathrm{~g}$ was delivered with an APGAR of 8 at 1 minute. Antibiotic prophylaxis was started after the delivery using 2 doses of cephalosporine during the first 24 hours. No postnatal and postpartum complications were 
observed. The VP shunt may be compressed by the gravid uterus and this may result in decreased cerebrospinal fluid flow through the shunt and increased intracranial pressure. So that, after the operation her neurological status improved quickly. On fourth postoperative day a neurosurgical examination showed no need for surgical intervention for the shunt. The patient was discharged from hospital on the seventh day without complications.
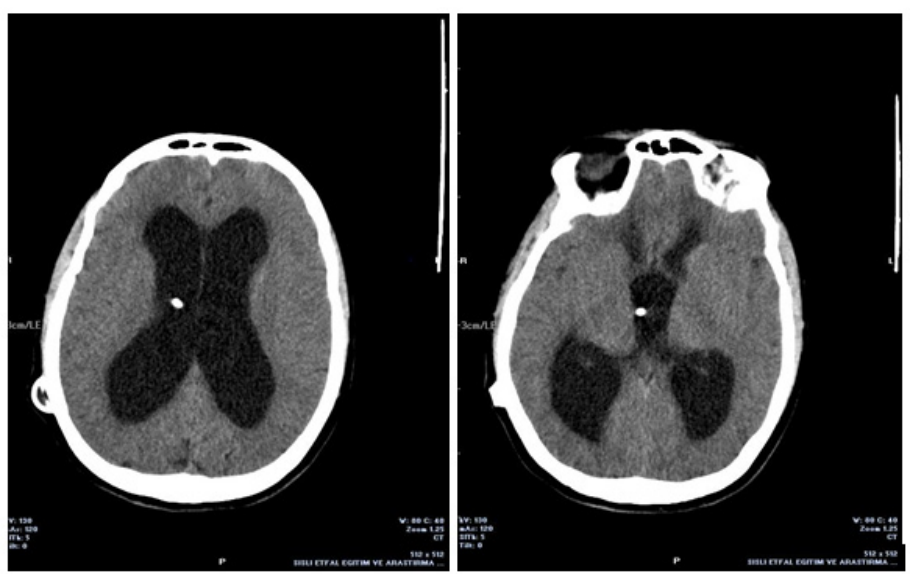

Figure I Cranial CT scan showed dilatation of both the lateral ventricles and the third ventricle and the presence of the ventriculoperitoneal shunt.

\section{Methods}

We performed a nonsystematic review of the literature. A literature analysis was performed on the electronic databases Medline considering papers in the time interval from 2000 to 2015 . We identified further studies by reviewing the reference list of key articles. The authors identified the most relevant studies, which included case reports and case series on the topic of management of VP shunt during pregnancy. We performed using key-terms "VP shunt during pregnancy, "cerebrospinal fluid shunt during pregnancy" and "pregnancy with VP shunt". After exclusion of articles that were not relevant to the focus of our study 15 relevant articles were retrieved and included in the present review. We report a case of pregnancy in a patient with ventriculoperitoneal shunt malfunction and reviewed the currently available literature regarding pregnancy and delivery in patients with VP shunt. We evaluated the clinical significance of the management of VP shunt complications, possible complications of gestation, mode of delivery and anesthesia technique during pregnancy. We discussed ideal management of VP shunt during pregnancy and especially the importance of the multidisciplinary approach in the event of pregnancy in women with VP shunt.

\section{Discussion}

VP shunts are a definitive treatment for hydrocephalus. ${ }^{5} \mathrm{~A}$ VP shunt reduces the morbidity and mortality of hydrocephalus considerably. This method has improved the prognosis of patients with hydrocephalus and has increased the number of women reaching childbearing age. ${ }^{7}$ In this review we would like to discuss VP shunt cases during pregnancy. Women with VP shunts require special management during the course of pregnancy with a team of neurosurgeons, obstetricians and anesthesiologists..$^{10}$ Interdisciplinary management of pregnant woman with VP shunts should be performed during the preconception, antenatal, and postnatal periods as well as during the delivery. ${ }^{2,5,7}$

\section{Preconception}

Women with VP shunts need to be fully evaluated before pregnancy by both neurosurgeons and obstetricians. MRI images should be regularly obtained to assess the ventricle system. ${ }^{6}$ In our case, the patient had the approval for pregnancy from her neurosurgeon at the preconceptional period. Hwang et al. ${ }^{5}$ highlighted the importance of cranial imaging (CT/MRI) before conception for the management of pregnant women with a VP shunt. The cranial imaging before the conception is important for determining whether the shunt is functioning properly before pregnancy and to yield a baseline value for future comparison if ventricular dilatation occurs during pregnancy. ${ }^{5}$ Therefore, it is necessary to make a preconception examination which will prevent potential complications.

\section{Complications during pregnancy}

The complications during pregnancy in women with VP shunts varies with the gestational week. The VP shunt catheter is frequently obstructed during the third trimester as a result of increased intraabdominal pressure. ${ }^{5,6}$ Infection of the shunt, obstruction, overdrainage and mechanical complications are the major possible reasons for shunt revisions. ${ }^{4}$ The malfunction of shunts in pregnant women remains a challenging medical condition for both neurosurgeons and obstetricians. The symptoms of hydrocephalus in patients with shunt malfunction include headache, nausea, vomiting, drowsiness, gait imbalance, ataxia, and seizures. ${ }^{5,6}$

Nikolov et al. ${ }^{3}$ studied 12 pregnant cases with preexisting shunts. Nine cases had VP shunts and three cases had ventriculoatrial (VA) shunts. They concluded that the presence of a cerebral shunt does not affect the pregnancy. Haeussler et al. ${ }^{11}$ reported three patients in their series with VP shunts had no shunt-related complications during these pregnancies. Liakos et al. ${ }^{2}$ conducted a questionnaire providing information on medical history, shunt performance during pregnancy, management of delivery and pregnancy outcomes. Seventy respondents completed the questionnaire. Three women had seizures during pregnancy, nine women reported increased headaches during pregnancy, and twelve women described abdominal pains during the course of pregnancy especially increased frequency of painful episodes during the first and third trimesters. Shunt malfunctions and revisions occurred in four women during pregnancy and in 13 women within six months of postpartum period. No acute malfunctions requiring immediate revision occurred during delivery, although two women reported severe headaches during labor. They concluded that maternal shunts during pregnancy increased the incidences of complications for some patients however; with proper management those patients can have a normal pregnancy and labor. So the presence of a VP shunt is not a contraindication for pregnancy. Karanth et al. ${ }^{12}$ reported a pregnant patient with VP shunt malfunction and performed intrapartum shunt revision during cesarean section at term. Rees et al. ${ }^{13}$ inserted a new VP shunt in a pregnant patient at 20 weeks of gestation due to VP shunt malfunction. In our case, the patient was examined in the preconception period she faced with shunt complications during the third trimester. Despite the shunt malfunctioning her delivery was successful without intrapartum and postpartum complications. Moreover, after the delivery no intervention was needed for her shunt.

\section{VP malfunctions managament}

The standard procedure for shunt malfunctions during pregnancy has not been established yet. However, low rates of shunt malfunctions and revisions were found in pregnant women. ${ }^{6}$ Murakami et al. ${ }^{1}$ recommended ventriculoatrial (VA) shunt replacement as a treatment option for the management of VP shunt malfunction during pregnancy. Riffaud et al. ${ }^{14}$ used endoscopic third ventriculostomy as a treatment modality in newly diagnosed obstructive hydrocephalus and malfunction of a preexisting shunt. Sasawaga et al. ${ }^{15}$ used a flushing device in a pregnant patient with neurological deterioration 
due to VP shunt malfunction. The neurosurgeons performed pumping with a flushing device for the blocked shunt system. Sova et al. ${ }^{16}$ performed shunt replacement for treatment of shunt malfunction 3 weeks after the delivery. In another report external drainage of the left ventricle was performed under general anesthesia. ${ }^{6}$ On the other hand in our case and in the case of Schiza et al. ${ }^{7}$, there was not a need for shunt intervention because neurologic symptoms improved after the ceserean section. Fletcher et al. ${ }^{17}$ performed cesarean section with simultaneous shunt revision in patient had a possible blocked shunt Some researcher performed intrapartum shunt revision in patients with shunt malfunction. Our patient did not need surgical intervention for the shunt.

Magnetic resonance imaging seems to be a safe, effective tool for monitoring ventricular dilatation and diagnosing shunt failure in both pregnant and non-pregnant women.

For women who are in their second trimester and a full term birth is expected, shunt revision or VA shunts should be tried as a first treatment option. For women in their late third trimester, vaginal delivery or cesarean section would be an appropriate treatment without any intervention. The patient's neurological status and the gestational age of the fetus are the two most important parameters when deciding on a shunt intervention or delivery.

\section{Management of delivery}

Most authors considered vaginal delivery as the first option in women with VP shunts. Vaginal delivery should be attempted unless a cesarean section is inevitably required for obstetrics or neurosurgical reasons. ${ }^{6,9}$ In some studies, in patient with preterm delivery by Cesarean section should be recommended. ${ }^{16,17}$ Freo et al. ${ }^{8}$ reported that a rapidly deteriorating level of consciousness necessitates urgent and simultaneous cesarean delivery and neurosurgical intervention. In our case we prefered to perform an emergency cesarean section due to the patients rapid neurological detoriation. Vybíhal et al. ${ }^{9}$ reported that a primary cesarean section is preferred in patients with obstructive hydrocephalus or neurological deterioration in shunt malfunction cases. Nikolov et al. ${ }^{3}$ suggested vaginal delivery in women with cerebrospinal fluid shunts can be succesful with adequate analgesic medication. However in rapid neurological deteriation an emergency cesarean section should be kept in mind and performed as soon as possible.

\section{Mode of anesthesia}

There is no consensus about the anaesthesia technique on VP shunt cases. The choice of the anaesthetic technique for cesarean delivery in a patient with a malfunctioning VP shunt depends on various factors, e.g. the mother's neurological condition, her wishes, the presence or absence of elevated intracranial pressure (ICP), the possibility of a difficult airway and whether the delivery is emergent or planned. ${ }^{7}$ The anesthesia procedure varied in several reports on deliveries of VP shunt patients.

Some anesthesiologists preferred general anesthesia over spinal anesthesia because general anesthesia is relatively safe, could decrease cranial pressure and it eliminates the possibility of VP shunt infection that may arise with spinal anesthesia. ${ }^{6}$ Freo et al suggested that patient with increased ICP, general anesthesia is suitable, provided the agents used have minimal adverse effects on mother and fetus. Haeussler et al. ${ }^{11}$ reported that spinal anaesthesia for caesarean section is commonly used in women with VP shunt. Epidural anesthesia is not recommended by some authors because of the possibility of an inadvertent dural puncture resulting in contamination of the VP shunt. ${ }^{5}$ In a case report a VP shunt revision and caesarean delivery were performed under general anaesthesia. ${ }^{8}$ In another case $^{7}$ a patient had a scheduled cesarean section delivery at the 30th week of gestation under epidural anesthesia. Our case was performed under spinal anesthesia without any postoperative complication including infection.

\section{The role of prophylactic antibiotic coverage}

Women with VP shunts do not seem to have a higher rate of postpartum infections compared to women without shunts. ${ }^{2,10}$ Liakos et $\mathrm{al}^{2}{ }^{2}$ support the use of routine prophylactic antibiotics for cesarean sections, however the effectiveness of antibiotic prophylaxis in preventing shunt infections in this population has not been studied. Landwehr et al. ${ }^{18}$ reported that antibiotics are not needed routinely in uncomplicated vaginal deliveries to prevent shunt infections, but they did not give recommendation pertaining to cesarean section deliveries. There are some papers debating on prophylactic antibiotic use both in vaginal delivery and $\mathrm{C} / \mathrm{S}$ for patients with VP shunts. ${ }^{10,18}$ Some rare cases of shunt infection after vaginal delivery or $\mathrm{C} / \mathrm{S}$ were reported. ${ }^{10,19}$ So that, in our case, antibiotic prophylaxis was started after the delivery using 2 doses of cephalosporine during the first 24 hours.

Case reports on VP shunts during pregnancy including interventions, outcomes and complications were shown in Table 1.

Table I Case reports on VP shunts during pregnancy including interventions, outcomes and complications VPVentriculoperitoneal Shunt, C/S Cesarean Section. *Obstetric endications, ** Neurologic endications

\begin{tabular}{|c|c|c|c|c|c|c|c|}
\hline Authors & Age & $\begin{array}{l}\text { Gestational } \\
\text { age (Week) }\end{array}$ & $\begin{array}{l}\text { Complain at the } \\
\text { admission }\end{array}$ & $\begin{array}{l}\text { Intervention by } \\
\text { neurosurgeons }\end{array}$ & $\begin{array}{l}\text { Complications } \\
\text { during pregnancy }\end{array}$ & $\begin{array}{l}\text { Delivery } \\
\text { method }\end{array}$ & $\begin{array}{l}\text { Anestesia } \\
\text { or analgesia } \\
\text { procedure }\end{array}$ \\
\hline Wang et al. ${ }^{6}$ & 18 & 30 & $\begin{array}{l}\text { Acute disturbance of } \\
\text { consciousness }\end{array}$ & $\begin{array}{l}\text { External drainage } \\
\text { of ventricle }\end{array}$ & $\begin{array}{l}\text { Premature rupture of } \\
\text { membrane }\end{array}$ & Vaginal delivery & None \\
\hline Bursac et al. ${ }^{4}$ & 32 & Term & $\begin{array}{l}\text { No neurologic } \\
\text { complications }\end{array}$ & No & No & Vaginal delivery & $\begin{array}{l}\text { Epidural } \\
\text { Anestesia }\end{array}$ \\
\hline Schiza et al. ${ }^{7}$ & 35 & 30 & $\begin{array}{l}\text { Bilateral vision } \\
\text { disturbance, } \\
\text { speech, gait } \\
\text { problems, dysphagia, } \\
\text { hypertonicity }\end{array}$ & No & Preterm Delivery & $\mathrm{C} / \mathrm{S}^{* *}$ & $\begin{array}{l}\text { Epidural } \\
\text { Anestesia }\end{array}$ \\
\hline $\begin{array}{l}\text { Karanth et } \\
\text { al. }^{12}\end{array}$ & 23 & Term & $\begin{array}{l}\text { At } 29 \text { th week; } \\
\text { headache, projectile } \\
\text { vomiting, giddiness }\end{array}$ & $\begin{array}{l}\text { Intrapartum shunt } \\
\text { revision }\end{array}$ & Shunt malfunction & $\mathrm{C} / \mathrm{S}^{* *}$ & General \\
\hline
\end{tabular}


Table Continued.....

\begin{tabular}{|c|c|c|c|c|c|c|c|}
\hline Hwang et al. $^{5}$ & 32 & Term & $\begin{array}{l}\text { Postpartum severe } \\
\text { headache, nausea }\end{array}$ & $\begin{array}{l}\text { Flushing device } \\
\text { was pumped }\end{array}$ & $\begin{array}{l}\text { Postpartum VP shunt } \\
\text { malfunction }\end{array}$ & $\mathrm{C} / \mathrm{S}^{*}$ & None \\
\hline $\begin{array}{l}\text { Murakami et } \\
\text { al.' }\end{array}$ & 27 & 26 & $\begin{array}{l}\text { At } 26 \text { th week; } \\
\text { headache, nausea, } \\
\text { vomiting, double vision }\end{array}$ & $\begin{array}{l}\text { I. CSF aspirated } \\
\text { from the reservoir } \\
\text { of the shunt } \\
\text { system } \\
\text { 2. Replacement of } \\
\text { VP shunt with aVA } \\
\text { shunt }\end{array}$ & & $\begin{array}{l}\text { Spontaneous } \\
\text { vaginal delivery } \\
\text { (at term) }\end{array}$ & None \\
\hline Freo et al. $^{8}$ & 35 & 36 & $\begin{array}{l}\text { Headache, nausea and } \\
\text { memory loss }\end{array}$ & $\begin{array}{l}\text { Intrapartum shunt } \\
\text { revision }\end{array}$ & Shunt malfunction & $\mathrm{C} / \mathrm{S}^{* *}$ & General \\
\hline $\begin{array}{l}\text { Haeussler et } \\
\text { al." } \\
\text { (Case Series) }\end{array}$ & $22,24,29$ & Term & & No & No & $\begin{array}{l}2 \text { Vaginal } \\
\text { delivery, I C/S* }\end{array}$ & General \\
\hline $\begin{array}{l}\text { Nikolov et } \\
\text { al. }^{3} \\
\text { (Case series) }\end{array}$ & $\begin{array}{l}19-36 \\
\text { (Range) }\end{array}$ & $\begin{array}{l}9 \text { pregnancy } \\
\text { term, } 2 \\
\text { preterm and } \\
\text { I premature } \\
\text { delivery }\end{array}$ & & $\begin{array}{l}\text { Postpartum } \\
\text { only one case } \\
\text { was performed } \\
\text { revision }\end{array}$ & Premature delivery & $\begin{array}{l}5 \text { case vaginal, } 4 \\
\text { case } C / S\end{array}$ & $\begin{array}{l}\text { Epidural, } \\
\text { general, spinal }\end{array}$ \\
\hline Rees et al. $^{13}$ & 27 & 20 & Status epilepticus & $\begin{array}{l}\text { A new VP shunt } \\
\text { placed }\end{array}$ & In utero mort & $\begin{array}{l}\text { Induced vaginal } \\
\text { delivery }\end{array}$ & None \\
\hline \multirow[t]{2}{*}{$\begin{array}{l}\text { Fletcher et } \\
\text { al. }{ }^{17}\end{array}$} & 25,32 & Term and 34 & $\begin{array}{l}\text { First patient: No } \\
\text { medical problem }\end{array}$ & $\begin{array}{l}\text { First patient: No } \\
\text { medical problem }\end{array}$ & $\begin{array}{l}\text { First patient: No } \\
\text { medical problem }\end{array}$ & $\begin{array}{l}\text { First patient: } \\
\text { Vaginal delivery }\end{array}$ & No data \\
\hline & & & $\begin{array}{l}\text { Second patient: } \\
\text { Worsening memory, } \\
\text { headache and urinary } \\
\text { incontinence }\end{array}$ & $\begin{array}{l}\text { Second patient: } \\
\text { Shunt revision }\end{array}$ & $\begin{array}{l}\text { Second Patient: } \\
\text { Preterm delivery }\end{array}$ & $\begin{array}{l}\text { Second Patient: } \\
\text { C/S** }\end{array}$ & \\
\hline $\begin{array}{l}\text { Sasagawa et } \\
\text { al. }{ }^{15}\end{array}$ & 27 & Term & $\begin{array}{l}\text { Gait disturbance at } 25 \\
\text { weeks of gestation }\end{array}$ & $\begin{array}{l}\text { Pumping of a } \\
\text { flushing device for } \\
\text { the shunt system }\end{array}$ & Shunt malfunction & $\begin{array}{l}\text { Vaginal delivery } \\
\text { (Term) }\end{array}$ & None \\
\hline Kane et al. ${ }^{10}$ & 19 & Term & $\begin{array}{l}\text { Postpartum non-focal } \\
\text { headache and fever }\end{array}$ & $\begin{array}{l}\text { A new VP shunt } \\
\text { replaced }\end{array}$ & $\begin{array}{l}\text { Postpartum VP shunt } \\
\text { infection }\end{array}$ & $\mathrm{C} / \mathrm{S}^{*}$ & No data \\
\hline Sova et al. ${ }^{16}$ & 27 & 34 & $\begin{array}{l}\text { Headache, double } \\
\text { vision and severe } \\
\text { Parinaud's syndrome }\end{array}$ & $\begin{array}{l}\text { Replacement of VP } \\
\text { shunt }\end{array}$ & $\begin{array}{l}\text { Preterm delivery and } \\
\text { shunt malfunction }\end{array}$ & $\mathrm{C} / \mathrm{S}^{* *}$ & No data \\
\hline $\begin{array}{l}\text { Liakos et al. }^{2} \\
\text { (Case series) }\end{array}$ & $\begin{array}{l}\text { I8-4I } \\
\text { (Range) }\end{array}$ & & Especially headache & $\begin{array}{l}\text { Shunt revisions } \\
\text { occurred four } \\
\text { women during } \\
\text { pregnancy }\end{array}$ & $\begin{array}{l}\text { No signs of Shunt } \\
\text { malfunction were } \\
\text { identified in } 100 \\
\text { of the pregnancies } \\
\text { described in } \\
\text { this series } 32 \\
\text { miscarriages, } 5 \\
\text { preterm delivery }\end{array}$ & $\begin{array}{l}\text { Vaginal and C/S } \\
\text { delivery }\end{array}$ & \\
\hline
\end{tabular}

\section{Conclusion}

We suggest a general outline for the management of VP shunts during pregnancy as follows:

a. Women with VP shunts need to undergo consultation prior to pregnancy and MRI images should be regularly obtained to assess the ventricle system. The baseline MRI before pregnancy is important for follow up.

b. Vaginal delivery is considered as the first option by most authors in women with VP shunts. Vaginal delivery should be attempted unless a cesarean section is inevitably required for any obstetric or neurosurgical reasons.

c. There is no consensus about the anaesthetic technique. However, the choice of the anaesthetic technique depends on obstetric and neurologic conditions.

d. An antibiotic prophylaxis is optional, but we recommend it especially in epidural or spinal anesthesia.

e. For patients in their second trimester different interventions can be tired for obstructed cases but in the third trimester vaginal delivery or cesarean section would be the appropriate treatment. In these women the management must be individualized, multi disciplined and close collaboration with the neurosurgeon, obstetrician and anesthesiologist offer the best chance of normal pregnancy and delivery.

\section{Acknowledgement}

None.

\section{Conflict of Interest}

The author declares that they do not have any conflicts of interest.

\section{References}

1. Murakami M, Morine M, Iwasa T, et al. Management of maternal hydrocephalus requires replacement of ventriculoperitoneal shunt with ventriculoatrial shunt: a case report. Arch Gynecol Obstet. 2010;282(3):339-342 
2. Liakos AM, Bradley NK, Magram G, et al. Hydrocephalus and the reproductive health of women: The medical implications of maternal shunt dependency in 70 women and 138 pregnancies. Neurol Res. 2000;22(1):69-88.

3. Nikolov A, Surchev Zh, Nalbanski B, et al. Pregnancy and delivery in women with cerebrospinal fluid shunt due to hydrocephalus. Akush Ginekol (Sofiia). 2008;47(2):3-10.

4. Bursac D, Kulas T, Persec J, et al. Pregnancy and vaginal delivery in epidural analgesia in woman with cerebrospinal fluid shunt. Coll Antropol. 2013;37(4):1343-1345.

5. Hwang SC, Kim TH, Kim BT, et al. Acute shunt malfunction after cesarean section delivery: A case report. J Korean Med Sci. 2010;25(4):647-650.

6. Wang X, Wang H, Fan Y, et al. Management of acute hydrocephalus due to pregnancy with ventriculoperitoneal shunt. Arch Gynecol Obstet. 2013;288(5):1179-1182.

7. Schiza S, Stamatakis E, Panagopoulou A, et al. Management of pregnancy and delivery of a patient with malfunctioning ventriculoperitoneal shunt. $J$ Obstet Gynaecol. 2012;32(1):6-9.

8. Freo U, Pitton M, Carron M, et al. Anesthesia for urgent sequential ventriculoperitoneal shunt revision and cesarean delivery. Int $J$ Obstet Anesth. 2009;18(3):284-287.

9. Vybíhal V, Gerychová R, Janků P, et al. Pregnancy and delivery in patients with an implanted shunt for hydrocephalus. Ceska Gynekol. 2014;79(4):309-313.

10. Kane JM, Jackson K, Conway JH. Maternal postpartum group B betahemolytic streptococcus ventriculoperitoneal shunt infection. Arch Gynecol Obstet. 2004;269(2):139-141.
11. B Haeussler, E Laimer, J Hager, et al. Pregnancy, Delivery and Postpartum Care of Women with Ventriculo-Peritoneal Shunted Hydrocephalus: a case series. Internet J Gynecology \& Obstetrics. 2009;12(2):1-5.

12. Karanth S, Sheela CN, Chhabra M. Malfunction of ventriculoperitoneal shunt during pregnancy: A case report. Int $J$ Pharm Biomed Res. 2011;2:266-268.

13. Rees GJ, Francis HC, Sizer AR Convulsions in an undiagnosed pregnancy due to blocked ventriculoperitoneal shunt. J Obstet Gynaecol. 2008;28(5):533-534.

14. Riffaud L, Ferre JC, Carsin-Nicol B, et al. Endoscopic third ventriculostomy for the treatment of obstructive hydrocephalus during pregnancy. Obstet Gynecol. 2006;108:801-804.

15. Sasawaga Y, Sasaki T, Fuji T, et al. Ventriculoperitoneal shunt malfunction due to pregnancy. No Shinkei Geka. 200634(2):181-187.

16. Sova M, Smrcka M, Baudysova O, et al. Management of a shunt malfunction during pregnancy. Bratisl Lek Listy. 2001;102(12):562-563.

17. Fletcher H, Crandon IW, Webster D. Maternal hydrocephalus in pregnancy and delivery: A report of two cases. West Indian Med J. 2007;56(6):558-559.

18. Landwehr JB, Isada NB, Pryde PG, et al. Maternal neurosurgical shunts and pregnancy outcome. Obstet Gynecol. 1994;83(1):134-137.

19. Fox BC. Delayed-onset postpartum meningitis due to group B Streptococcus. Clin Infect. 1994;19:350. 